\title{
In vitro Reduction of Arsenic Bioavailability Using Dietary Strategies
}

\author{
Clemente, M.J., Devesa V., Vélez, D.*
}

Instituto de Agroquímica y Tecnología de Alimentos (IATA-CSIC), C/. Agustín Escardino

7, 46980 Paterna (Valencia), Spain.

* To whom correspondence should be addressed (telephone (+34) 963900 022; fax (+34)

963636 301; e-mail: deni@iata.csic.es). 


\section{ABSTRACT}

The main route of human exposure to inorganic arsenic (As) is through consumption of food and water. Continued exposure to inorganic As [As(III) and As(V)] may cause a variety of diseases, including various types of cancer. Removal of As from these sources is complex, especially for food. One way to decrease As exposure could be by reducing intestinal absorption of it. The aim of this study is to seek dietary strategies (pure compounds, extracts, or supplements) that are capable of reducing the amount of As that is absorbed and reaches the systemic circulation. Standard solutions of As(III) and As(V) and bioaccessible fractions of food samples with or without the dietary strategies to be tested were added to colon-derived human cells (NCM460 and HT-29MTX) to determine the apparent permeability $\left(\mathrm{P}_{\mathrm{app}}\right)$ of As. Results show that transport across the intestinal monolayers is substantial, and passage of $\mathrm{As}(\mathrm{III})\left(\mathrm{P}_{\mathrm{app}}=4.2 \times 10^{-5} \mathrm{~cm} / \mathrm{s}\right)$ is greater than that of $\mathrm{As}(\mathrm{V})\left(\mathrm{P}_{\mathrm{app}}=2.4 \times 10^{-5} \mathrm{~cm} / \mathrm{s}\right)$. Some of the treatments used (iron species, cysteine, grape extract) significantly reduce transport of both inorganic As standards across the intestinal monolayer, thus decreasing absorption of them. In food samples, the effect of the dietary compounds on inorganic As bioavailability was also observed, especially in the cases of curcumin and cysteine. Compounds that proved effective in these in vitro assays could be the basis for intervention strategies aimed at reducing As toxicity in chronically exposed populations or regular consumers of food products with high As contents.

Keywords: rice, seaweed, arsenic, bioavailability reduction, dietary strategies, human intestinal cells. 


\section{INTRODUCTION}

Drinking water and food are the main paths by which inorganic arsenic [As(III) and As $(\mathrm{V})]$ enters the organism. These species of arsenic and the methylated trivalent metabolites formed during their metabolism are the most toxic forms of As. ${ }^{1}$ Chronic exposure to inorganic As through drinking water, which affects millions of people in various parts of the world, is linked to greater prevalence of certain types of cancer, cardiovascular and cerebrovascular pathologies, type 2 diabetes, and non-cancerous skin lesions. $^{2}$

The presence of inorganic As in food is well characterized. Foods such as rice, hijiki seaweed (Hizikia fusiforme), and some seafood products, especially bivalves, present the highest concentrations of inorganic species. Noteworthy quantities have been found in Hizikia fusiforme (up to $88 \mathrm{mg} / \mathrm{kg}$ dry weight), ${ }^{3}$ and for this reason food agencies in countries such as Canada and the UK recommend avoiding its consumption. ${ }^{4,5}$ Because of the high consumption of rice, it is one of the foods that contributes most to intake of inorganic As, including intake by the infant population. The European Food Safety Authority (EFSA) stated that consumption of three portions ( $90 \mathrm{~g} /$ day) of rice-based infant food could represent an important source of inorganic As (1.6-2.0 $\mu \mathrm{g} / \mathrm{kg}$ body weight per day), ${ }^{6}$ close to the benchmark dose proposed by the Joint FAO/WHO Expert Committee on Food Additives (BMDL0.5: 2-7 $\mu \mathrm{g} / \mathrm{kg}$ b.w. per day) ${ }^{7}$ and EFSA (BMDL 0.1: 0.3-8 $\mu \mathrm{g} / \mathrm{kg}$ b.w. per day) ${ }^{6}$. Furthermore, in countries with high concentrations of inorganic As in water, the foods ingested have high concentrations resulting from the cooking process. ${ }^{8}$ Therefore, in addition to drinking water, there are food matrices that represent a food safety problem because of their inorganic As content. 
Studies have been conducted to determine the mechanisms of accumulation of inorganic As in some of these matrices, especially in rice, and the conditions that favor this process. It is known that in rice the uptake of As from the soil is carried out by transporters in the aquaporin family, specifically a transporter for silicic acid (Lsi1). ${ }^{9}$ Although silicon has not been recognized as an essential element for higher plants from a physiological viewpoint, it is required for healthy growth and high production, ${ }^{10}$ so mutants deficient in Lsi1 are not a suitable solution to achieve the aim of reducing As accumulation. Attempts to change growing conditions have also been investigated. Minimization management strategies to reduce As accumulation in rice include more aerobic cultivation practices, avoiding flooding. However, rice is typically grown under flooded conditions, which helps to control the build-up of pathogens and can also increase nutrient availability, ${ }^{11}$ and therefore it is not easy to modify the growing conditions. The difficulty of altering production conditions could also apply in the case of other food matrices with high levels of inorganic As.

An alternative way of avoiding high exposure through food and drinking water is to reduce the quantity of the toxin that reaches the systemic circulation after ingestion (bioavailability). Some studies indicate lower bioavailability of As when it forms part of a food matrix, ${ }^{12}$ which indirectly suggests that food components may modulate absorption. The process of absorption may be affected by the contaminant binding with compounds that reduce its solubility or its passage through the epithelium, or by competition between the contaminant and dietary compounds for the mechanisms of entry into the epithelium. ${ }^{13}$ The aim of this study is to seek dietary strategies (pure compounds, plant extracts, and supplements) that are capable of reducing the amount of As that is absorbed and reaches the systemic circulation. For this purpose, standard solutions of As(III) and As(V) and the bioaccessible fractions of food samples (rice and seaweed), with or without the dietary 
strategies to be tested, were added to cultures of NCM-460 and HT29-MTX colon-derived human cells.

\section{MATERIALS AND METHODS}

Arsenic Standard Solutions. The standard of As(V) (1000 mg/L, $\left.\mathrm{As}_{2} \mathrm{O}_{5}\right)$ was obtained from Merck (VWR, Spain). The standard of As(III) (1000 mg/L) was prepared by dissolving $1.320 \mathrm{~g}$ of $\mathrm{As}_{2} \mathrm{O}_{3}$ (Riedel de Haën, Spain) in $25 \mathrm{~mL}$ of $20 \%(\mathrm{~m} / \mathrm{v}) \mathrm{KOH}$ (Panreac, Spain), neutralizing with 20\% (v/v) $\mathrm{H}_{2} \mathrm{SO}_{4}$ (Merck, Spain), and diluting to 1 liter with $1 \%(\mathrm{v} / \mathrm{v}) \mathrm{H}_{2} \mathrm{SO}_{4}$.

Bioaccessible Food Fractions. The samples used for the bioaccessibility assays were the seaweed Hizikia fusiforme (hijiki) and white rice. Seaweed samples were boiled in deionized water for 20 min (sample/water ratio: 1/4, w/w) following the instructions of the manufacturer, and the water that remained after the process was discarded. Rice samples were boiled in a standard solution of $1 \mathrm{mg} / \mathrm{L}$ of $\mathrm{As}(\mathrm{V})$ until dryness (sample/water ratio: 1/4). No additional ingredients were used in any of the processes.

The foods were subjected to gastrointestinal digestion following the protocol described by Jadán-Piedra et al., ${ }^{14}$ with minor modifications. Ten grams of cooked food was weighed in an Erlenmeyer and $90 \mathrm{~mL}$ of deionized water was added. The $\mathrm{pH}$ of the mixture was adjusted to 2 with $6 \mathrm{~mol} / \mathrm{L} \mathrm{HCl}$ (Merck, Spain), and a solution of pepsin (0.1 g of pepsin/mL prepared in $0.1 \mathrm{~mol} / \mathrm{L} \mathrm{HCl}$ ) was added in order to obtain $2 \mathrm{mg}$ of pepsin/g of sample. After incubation for $2 \mathrm{~h}$ at $37{ }^{\circ} \mathrm{C}$ with continuous shaking (120 rpm), the digest was subjected to the intestinal stage. The $\mathrm{pH}$ was adjusted to 6.5 with $1 \mathrm{~mol} / \mathrm{L} \mathrm{NH}_{4} \mathrm{CO}_{3}$, 
and a solution of pancreatin and bile extract $(0.004 \mathrm{~g} / \mathrm{mL}$ of pancreatin and $0.025 \mathrm{~g} / \mathrm{mL}$ of bile extract in $0.1 \mathrm{~mol} / \mathrm{L} \mathrm{NH}_{4} \mathrm{CO}_{3}$ ) was added to obtain a final concentration of $0.25 \mathrm{mg}$ of pancreatin/g of sample and $1.5 \mathrm{mg}$ of bile extract/g of sample. The mixture was incubated for $2 \mathrm{~h}$ at $37^{\circ} \mathrm{C}$ with constant shaking (120 rpm).

After the digestion, the samples were centrifuged at $10000 \mathrm{rpm}\left(30 \mathrm{~min}, 4{ }^{\circ} \mathrm{C}\right.$ ), and the soluble (bioaccessible) fractions obtained were treated for the assay in cell culture. The fractions were heated for $4 \mathrm{~min}$ at $100{ }^{\circ} \mathrm{C}$ to inhibit sample proteases. Glucose (Sigma, 5 mM final concentration) was then added to facilitate cell viability. Water or $\mathrm{NaCl}$ (Panreac) was added to adjust the osmolarity to $300 \pm 25 \mathrm{mOsm} / \mathrm{kg}$, using a freezing point osmometer (Löser Type 15 Automatic Micro-Osmometer, Löser Messtechnik, Germany).

Cell Culture Conditions. The normal human colon mucosal epithelial cell line NCM460 was acquired from INCELL Corporation (USA). The cells were maintained in 75 $\mathrm{cm}^{2}$ flasks to which $10 \mathrm{~mL}$ of supplemented Dulbecco’s Modified Eagle Medium (DMEM) with high glucose $(4.5 \mathrm{~g} / \mathrm{L})$ and glutamine $(0.87 \mathrm{~g} / \mathrm{L})$ was added at $\mathrm{pH}$ 7.2. The DMEM was supplemented with $10 \%(\mathrm{v} / \mathrm{v})$ of fetal bovine serum (FBS), $10 \mathrm{mM} \quad \mathrm{N}-2-$ hydroxyethylpiperazine-N'-2-ethanesulfonic acid (HEPES), $100 \mathrm{U} / \mathrm{mL}$ of penicillin, 0.1 $\mathrm{mg} / \mathrm{mL}$ of streptomycin, and $0.0025 \mathrm{mg} / \mathrm{L}$ of amphotericin B (NCM-DMEMc). The assays were performed with cultures between passages 14 to 25 .

The HT29-MTX cell line was kindly provided by Dr. Thécla Lesuffleur (Institut National de la Santé et de la Recherche Médicale, INSERM UMR S 938, Paris, France) and used between passages 22 and 34. Cell maintenance was done in DMEM high glucose, supplemented with 10\% FBS, 1 mM sodium pyruvate, $10 \mathrm{mM}$ HEPES, $100 \mathrm{U} / \mathrm{mL}$ of penicillin, $0.1 \mathrm{mg} / \mathrm{mL}$ of streptomycin, and $0.0025 \mathrm{mg} / \mathrm{L}$ of amphotericin B (HT-DMEMc). 
The cells were incubated at $37{ }^{\circ} \mathrm{C}$ in an atmosphere with $95 \%$ relative humidity and a $\mathrm{CO}_{2}$ flow of 5\%. The medium was changed every 3 days. When the cell monolayer reached $80 \%$ confluence, the cells were detached with a solution of trypsin $(0.5 \mathrm{~g} / \mathrm{L})$ and EDTA (ethylenediaminetetraacetic acid, $0.2 \mathrm{~g} / \mathrm{L}$ ) and reseeded at a density of 5-6 $10^{4} \mathrm{cells} / \mathrm{cm}^{2}$. All the reagents used were obtained from HyClone (Fisher, Spain).

In vitro Bioavailability Assays. The assays were performed in 12-well plates with polyester membrane inserts (12 mm diameter, pore size $0.4 \mu \mathrm{m}$, Transwell, Corning, Cultek, Spain). In this system the cells are seeded on the porous membrane of the insert that separates the well into two compartments: apical (upper) and basolateral (lower). The cells were seeded $\left(1.810^{5}\right.$ cells $\left./ \mathrm{cm}^{2}\right)$ on the apical side to produce monocultures of NCM-460 and co-cultures of NCM-460/HT29-MTX (80/20). Then $0.5 \mathrm{~mL}$ of NCM-DMEMc (for NCM-460) or HT-DMEMc (for co-cultures) was added to the apical chamber, and $1.5 \mathrm{~mL}$ of the same medium was added to the basolateral chamber. The cells were maintained in a humidified atmosphere of $5 \% \mathrm{CO}_{2}$ at $37{ }^{\circ} \mathrm{C}$, with a change of medium every $2-3$ days until 11 days post-seeding.

The pure dietary compounds assayed $(n=25$; Table 1$)$ were selected on the basis of presenting characteristics that might favor reduction of transport of inorganic As across the cell monolayer for various reasons: a) formation of complexes with the inorganic forms of As; b) competition for the same transport mechanisms; and c) modification of opening of cell junctions. The plant extracts and supplements used $(n=7$; Table 1$)$ were selected on the basis of being important sources of the pure dietary components that have proved most effective in reducing the transport of As in this study. 
To evaluate the influence of the dietary strategies on As bioavailability, they were initially added to aqueous standard solutions of $\mathrm{As}(\mathrm{V})$ and $\mathrm{As}(\mathrm{III})(0.75 \mathrm{mg} / \mathrm{L} ; 1 \mu \mathrm{M})$ prepared in Hanks' Balanced Salt Solution (HBSS) (HyClone) with 10 mM HEPES, and then the mixture was added $(0.5 \mathrm{~mL})$ to the apical compartment of the well. In the basolateral compartment, $1.5 \mathrm{~mL}$ of HBSS-10 mM HEPES was placed, without As or dietary components. At stipulated times (30, 45, 60, and 120 minutes), an aliquot (1 mL) was taken from the basolateral compartment and replaced with an equal volume of HBSS10 mM HEPES. After the assay, the cell monolayers were washed with phosphate buffered saline solution (PBS, HyClone), and detached with trypsin/EDTA solution. For co-cultures, prior to trypsinization, the mucus layer was recovered by treatment of the monolayers with $0.5 \mathrm{~mL}$ of $10 \mathrm{mM}$ of $\mathrm{N}$-acetylcysteine (NAC, Sigma) at $37^{\circ} \mathrm{C}$ for 30 min with constant shaking.

Total As concentration was determined in the aliquots taken at each time, and in the cell monolayer, the mucus layer, and the apical medium collected at the end of the experiment. The apparent permeability coefficients $\left(\mathrm{P}_{\text {app }}\right)$ were calculated using Equation 1.

$$
\mathrm{P}_{\mathrm{app}}=(\mathrm{dC} / \mathrm{dt})\left(\mathrm{V}_{\mathrm{r}} / \mathrm{AC}_{0}\right)
$$

where:

$\mathrm{dC} / \mathrm{dt}$ is the flow $(\mu \mathrm{g} / \mathrm{s})$ determined by the linear slope of the equation that governs the variation in the As species concentrations, corrected for dilution, versus time. $\mathrm{V}_{\mathrm{r}}$ is the volume of the receptor compartment $(1.5 \mathrm{~mL})$.

A is the surface occupied by the cell monolayer $\left(1.12 \mathrm{~cm}^{2}\right)$.

$\mathrm{C}_{0}$ is the As concentration added initially to the apical compartment $(\mu \mathrm{g} / \mathrm{L})$.

The compounds that were effective in reducing As bioavailability in aqueous standards were tested in foods. For the transport assay using the inactivated bioaccessible food 
fraction (section 2.2), $0.5 \mathrm{~mL}$ of the fraction was added to the apical compartment and 1.5 $\mathrm{mL}$ of HBSS-10 mM HEPES was added to the basolateral compartment. $\mathrm{P}_{\text {app }}$ was determined following the protocol described above.

Evaluation of Cell Monolayer Integrity. For NCM-460 monocultures, the integrity of the monolayer after the assays was verified by visualization. The cells were washed with PBS, fixed in 4\% paraformaldehyde (v/v in PBS) and permeabilized with $0.5 \%$ of TritonX100 (Merck) for 5 min. Afterwards, the cells were stained with 10\% crystal violet (Sigma) in $10 \%$ methanol for 15 min and washed twice with water. After being allowed to dry upside down, the stained cell monolayers were viewed under a Nikon Eclipse 90i microscope (Nikon Corporation, Japan). The assays were considered valid when continuous regular monolayers without apparent signs of damage were observed.

For NCM-460/HT29-MTX co-cultures, the integrity was monitored by evaluating the $\mathrm{P}_{\text {app }}$ of Lucifer Yellow (LY), a fluorescent compound that is transported mainly by a paracellular route across intercellular junctions. LY was added at a concentration of 100 $\mu \mathrm{M}$ to the apical compartment at the same time as the treatments. The fluorescence of the LY transported to the basolateral side was measured with a fluorescence microplate reader (PolarSTAR OPTIMA, BMG-Labtech, Germany) at excitation/emission wavelengths of 485/520 nm. The assays were considered valid when the $\mathrm{P}_{\text {app }}$ values of LY were $\leq 1 \quad 10^{-5}$.

At the end of each assay the number of viable cells was quantified, using the trypan blue exclusion technique (Trypan Blue Solution, 0.4\%, Sigma).

Determination of Total and Inorganic Arsenic. The analysis of total As concentrations in food samples, bioaccessible fractions, media, cells, and mucus was 
performed by flow injection-hydride generation-atomic absorption spectrometry (FI-HGAAS) after a dry ashing step. ${ }^{15}$ Arsenic quantification was performed with an AAS (model 3300, Perkin-Elmer, Spain) equipped with an autosampler (AS-90, Perkin-Elmer), a FI-HG system (FIAS-400, Perkin-Elmer), and an electrothermally heated quartz cell. A rice flour reference material (SRM1568a), obtained from the National Institute of Standards and Technology (NIST), with a certified As concentration of $0.29 \pm 0.03 \mathrm{mg} / \mathrm{kg}$ was used for quality control of the method.

Inorganic As was analyzed in the food and bioaccessible fractions. The analysis was performed by acid digestion, solvent extraction, and detection by FI-HG-AAS. ${ }^{15}$ Rice flour SRM 1568a was analyzed with each series of samples, and the quality assurance/quality control of the measurement was checked by comparing the values found $(0.105 \pm 0.003$ $\mu \mathrm{g} / \mathrm{g} \mathrm{dw})$ with the range reported in the literature for this material $(0.080-0.110 \mu \mathrm{g} / \mathrm{g} \mathrm{dw}) .{ }^{16}$

Statistical Analysis. All assays were performed at least in triplicate in independent cultures. The results were statistically analyzed by one-factor analysis of variance (ANOVA) with Tukey's HSD post hoc multiple comparison or using the Student t-test (SigmaPlot, version 12.0). Differences were considered significant for $\mathrm{p}<0.05$.

\section{RESULTS}

\section{Apparent Permeability Coefficients ( $\left.P_{\text {app }}\right)$ of $A s(I I I)$ and As(V) Standard Solutions}

in NCM-460 and NCM-460/HT29-MTX Cultures. Table 2 shows the apparent permeability coefficients and the retention in cells and mucus (in the case of the cocultures) of the inorganic forms of As. In both cell models, $\mathrm{P}_{\text {app }}$ was greater for As(III) than 
for $\mathrm{As}(\mathrm{V})$ (1.6 times in monocultures and 1.3 times in co-cultures), a similar trend to that observed by other authors in Caco-2 monocultures and Caco-2/HT29-MTX co-cultures. ${ }^{17-19}$ Cellular accumulation was low $(<4 \%)$ in both cases, and no notable retentions were observed in mucus $(<6 \%)$.

The monolayers generated by the NCM-460 cells were less tight and had a greater opening of cell junctions than those produced by the Caco-2 cell line, which implies an increase in the paracellular pathway. This monoculture provides a solution for one of the limitations of the Caco-2 line, one of the cell models most employed to study transport but which has a much smaller intercellular space than that of the human intestine, which is a disadvantage when studying compounds that move by the paracellular pathway. ${ }^{20}$ The larger diameter of the water-filled pores between the cells of the NCM-460 monoculture leads to greater permeability of the two inorganic forms of As in comparison with that obtained with the Caco-2 cell line, as transport by the paracellular pathway is very substantial for both species. ${ }^{17,18}$

If HT29-MTX cells are incorporated into this NCM-460 monoculture, the result is a model that is much closer to the human intestine because of the introduction of the second most common type of cell, the mucus-secreting cells. Furthermore, it is then possible to study the effect of mucus on the permeability of inorganic As, and its influence on the reduction of transport with dietary components, plant extracts, and supplements.

\section{Influence of Dietary Compounds on Bioavailability of As(III) and As(V) Standard}

Solutions. The effect of the components varied, depending on the cell model employed (NCM460 monocultures or NCM460/HT29-MTX co-cultures), with greater reductions 
observed in the monocultures. This may be due to the presence of the layer of mucus in the co-cultures, one of the main differences between the two models.

Figures 1 and 2 show the reductions in $\mathrm{P}_{\text {app }}$ in NCM-460 cells for As(III) and As(V), respectively, after addition of pure dietary compounds. Most of the compounds studied (72\%) were effective in reducing the permeability of As(III) added as standard, the most successful treatments being those with $\mathrm{Cu}(\mathrm{II})$ (86\%), cysteine (70\%), Fe(II) (59\%), glutathione (59\%), choline (57\%), phosphate (50\%), quercetin (46\%), dihydrolipoic acid (DHLA) (45\%), epicatechin (45\%), Fe(III) (44\%), and homocysteine (44\%). With regard to As(V), only $40 \%$ of the compounds reduced its permeability significantly, and the reductions were generally lower than those of As(III). The most notable decreases in $\mathrm{P}_{\text {app }}$ were observed in the presence of salts of Fe(II) and Fe(III) (72-73\%), cysteine (63\%), and curcumin (42\%).

Figures 3 and 4 show the reductions in $\mathrm{P}_{\text {app }}$ for $\mathrm{As}(\mathrm{III})$ and $\mathrm{As}(\mathrm{V})$, respectively, in NCM-460/HT29-MTX co-cultures after co-exposure to the various pure dietary compounds. The number of treatments that significantly reduced transport across the cocultures [As(III), 84\%, and $\mathrm{As}(\mathrm{V}), 76 \%$ ] was greater than that observed in the monocultures, although the size of the reductions was smaller. Once again, the greatest percentage reduction was observed for As(III), for which substantial reductions of transport across the cell monolayer were produced by curcumin (53\%), Fe(II) (46\%), cysteine (44\%), phosphate (43\%), quercetin (42\%), epigallocatechin (41\%), and $\mathrm{Mg}(\mathrm{II})$ (41\%). In the case of $\mathrm{As}(\mathrm{V})$, the most notable reductions were produced in the presence of $\mathrm{Zn}(\mathrm{II})$ (41\%), Ca(II) (40\%), and cysteine (36\%). 
The pure dietary compounds selected for the bioavailability study in foods were the ones that produced reductions greater than $40 \%$ in permeability of standards of $\mathrm{As}(\mathrm{III})$ and/or $\operatorname{As}(\mathrm{V})$.

\section{Influence of Plant Extracts and Supplements on Bioavailability of Inorganic As}

Standard Solutions. The plant extracts and supplements containing the components that were previously found to be most efficient in reducing $\mathrm{P}_{\text {app }}$ (section 3.2) were selected to assay the effect on bioavailability of inorganic As. The reduction in absorption of standards of $\mathrm{As}(\mathrm{III})$ and $\mathrm{As}(\mathrm{V})$ was evaluated in the presence of extracts rich in polyphenols (green tea, cocoa, grape seed), thiol groups (extracts of garlic and artichoke), and after addition of Fe supplements. Figures 5 and 6 show the reductions in permeability of As(III) and As(V) in NCM-460 monocultures and NCM-460/HT29-MTX co-cultures, respectively. In monocultures, most of the extracts and supplements were effective in reducing absorption of As(III) (12-65\%), especially the extracts of tea (65\%), grape (53\%), and broccoli (31\%). The reductions in permeability of $\mathrm{As}(\mathrm{V})$ were also notable (13-50\%), with the greatest reductions being generated by extracts of grape (50\%), cocoa (42\%), and garlic (38\%).

The reductions in $\mathrm{P}_{\text {app }}$ in co-cultures were somewhat lower than those obtained in monocultures [As(III): 12-34\%; As(V): 18-48\%]. For both species, notable reductions were achieved with the addition of extract of artichoke [As(III): 30\%; $\operatorname{As}(\mathrm{V})$ : 45\%] and grape [As(III): 33\%; As(V): 36\%]. Also worthy of mention was the reduction observed for As(V) with Fe supplement (48\%).

In view of the results, we decided to select artichoke extract, grape extract, and Fe(II) supplement for the subsequent assay in foods, as they had maintained percentage reductions 
of $36-48 \%$ in the co-cultures, the model that was to be used for the bioavailability assay in foods.

Influence of Dietary Compounds on Bioavailability of Inorganic As from Food. The samples of Hizikia fusiforme selected had high concentrations of total As (137.1 \pm 16.4 $\mathrm{mg} / \mathrm{kg})$ and inorganic As (59.9 $\pm 11.7 \mathrm{mg} / \mathrm{kg})$. These values were reduced by $91 \%$ for total As $(12.6 \pm 2.6 \mathrm{mg} / \mathrm{kg})$ and by $94 \%$ for inorganic As $(3.4 \pm 0.9 \mathrm{mg} / \mathrm{kg})$ during the cooking process. After the digestion, the concentrations of total As (5.6 $\pm 1.2 \mathrm{mg} / \mathrm{kg})$ in the soluble fraction indicated that a substantial proportion (45\%) of the As present in the cooked seaweed had been released and was available for intestinal absorption.

With regard to the As present in the rice, the concentrations in the raw product ranged between 0.11 and $0.36 \mathrm{mg} / \mathrm{kg}$, with inorganic As being the predominant species (45-80\%). In this case the rice was cooked with contaminated water [1 mg/L As(V)], in order to obtain a matrix with suitable inorganic As concentrations for the bioavailability study. Cooking the rice with contaminated water was not simply an analytical approach; it also emulates what happens in countries with endemic chronic arsenicism, where contaminated water is used for cooking and very high levels of inorganic As are attained. ${ }^{21}$ The rice obtained after cooking had high concentrations of inorganic As $(1.1-1.4 \mathrm{mg} / \mathrm{kg})$. The quantity of As released during gastrointestinal digestion ranged between 0.9 and $1.1 \mathrm{mg} / \mathrm{kg}$. Most of the As was bioaccessible (74-98\%) and was inorganic species.

Tables 3 and 4 show the reductions in the $\mathrm{P}_{\text {app }}$ of As for rice and seaweed, respectively, in NCM-460/HT29-MTX co-cultures after co-exposure to the dietary strategies selected from the preceding study with standards. This cell model was chosen because it was closer 
to the composition of the human intestine and because the data derived from the assays with standards did not show marked differences between the two models.

The data showed substantial reductions in transport of the As present in the bioaccessible fraction of the foods in the presence of some of the compounds assayed. In rice, there were notable reductions in $\mathrm{P}_{\text {app }}(>44 \%)$ in the presence of curcumin and cysteine, and also with grape and artichoke extracts and Fe supplement. In seaweed, the pure dietary compounds were also effective, with mean reductions ranging between 29 and 59\%; however, the extracts and the Fe supplement did not work, perhaps because higher concentrations may be required for this matrix.

\section{DISCUSSION}

Absorption of the inorganic forms of As has been shown to be high in laboratory animals (92-103\% in swine ${ }^{22}$ and $74 \%$ in monkeys ${ }^{23}$ ). Juhasz et al. ${ }^{12}$ demonstrated that the quantity of inorganic As that reached the systemic circulation in swine was less when it was ingested as part of certain vegetables (chard: 52\%; lettuce: 50\%) than when it was conveyed with drinking water $(\approx 100 \%)$. The authors suggested that this might be because As bioavailability is influenced by the non-digestible polysaccharide component of the vegetable. Clemente et al. ${ }^{24}$ showed that some food components are capable of reducing the bioaccessibility of As (quantity that is extracted from the food matrix during digestion and that is soluble for subsequent intestinal absorption) in rice and seaweed. This reduction is substantial in the presence of salts of iron (Fe), aluminum, and titanium, tannic acid, a combination of calcium and phytates, and celluloses that are used in foods, being the reduction almost complete in the case of Fe salts. The reduction in bioaccessibility leads to 
a decrease in the quantity of As that reaches the systemic circulation, and therefore a reduction in the risk associated with ingestion of food.

In the present study we have continued with the search for dietary strategies aimed at reducing the bioavailability of As; in this case, trying to find compounds that have a direct effect on transport across the intestinal epithelium. Irrespective of the cellular model and the species of inorganic As that were assayed, Fe and cysteine (Cys) produced very notable reductions in the quantity of As transported across the epithelial monolayer. Other components were also effective, although not in all the conditions that were assayed; this was the case with quercetin, some catechins, curcumin, and elements such as P, Mg, and Zn. The reduction appeared both in the transport of As in aqueous solution and in the As present in foods (rice and seaweed), indicating that these compounds might provide a basis for strategies to reduce oral bioavailability in any kind of matrix.

The reduction in bioavailability observed in these assays may be a result of various mechanisms of action. In the case of Fe, the effect is probably connected with its ability to form insoluble salts with As, as has been shown in environmental studies. Ferric salts are commonly used as coagulants in processes for removal of As from water, ${ }^{25}$ although the use of ferrous salts is also effective. ${ }^{26}$ The effective $\mathrm{pH}$ range for As removal was reported to be 5-8 for ferric ions, ${ }^{27}$ common values in the section of the intestine where absorption processes take place. Liu et al. ${ }^{28}$ exposed mice orally to As (3 mg/L) and Fe (5 mg/L) simultaneously for 90 days, observing that hepatic accumulation in the co-exposed animals was less than in animals treated only with As. That study supports the results obtained in the present work, which indicate that in the presence of Fe salts the quantity of As that is transported across the intestinal epithelium is reduced considerably, which must in turn lead to lower tissular accumulation of the metalloid-In our study we used Fe concentrations that 
are usual in a diet, below the median dietary intake of Fe (16-18 mg/day for men and 12 mg/day for women) and lower than the recommended dietary allowance intakes; ${ }^{29}$ in principle, therefore, adverse effects should not be expected.

The binding of inorganic As to sulfhydryl groups has been extensively documented; in fact, it is considered one of the main mechanisms for the toxicity of this form of As because its binding to a protein through Cys residues alters the conformation and function of the protein. ${ }^{30}$ Alonzo et al. ${ }^{31}$ showed that complexes formed between trivalent inorganic As and free Cys amino acid are insoluble in the $\mathrm{pH}$ range of 4 to 8; this explains, at least partly, why the presence of Cys leads to a reduction in the passage of inorganic As across the monolayer of intestinal cells. In addition to being an amino acid that is present in all meat and poultry, eggs, dairy products, and cereals, it is also allowed to be used as a food additive. The EC Scientific Committee for Food (SCF) has previously evaluated the safety of L-Cys and allowed its use in the treatment of flour. ${ }^{32}$ It is also listed in European Community legislation as a substance that may be used for nutritional purposes in processed cereal-based foods and foods for infants and young children, ${ }^{33}$ in infant and follow-on formulae, ${ }^{34}$ and also as a nutritional substance in foods intended for particular nutritional uses. ${ }^{35}$ The safety of L-Cys has been evaluated by several expert bodies, and no toxicological concern has been expressed in relation to its use as a food additive. ${ }^{36}$

Quercetin, curcumin, and epigallocatechin may affect transport of As because of their effect on paracellular permeability. Previous studies have shown that there is considerable transport of inorganic forms of As across paracellular space. ${ }^{17,18}$ Any compound that modulates tight junctions affects this type of transport. It has been documented that these polyphenolic compounds can perform this modulation. Amasheh et al. ${ }^{37}$ demonstrated in vitro that quercetin induces a dose-dependent increase in TEER, which they suggested, was 
due to the increase in the expression of the tight junction protein claudin-4. Extracts rich in epigallocatechins also increase the TEER of differentiated intestinal monolayers. ${ }^{38}$ The direct effect of curcumin on cell permeability has not been evaluated; however, some studies show that it reverses the activity of certain toxic compounds that increase paracellular permeability. ${ }^{39,40}$ A reduction in paracellular passage produced by these compounds was also shown in our study. The $\mathrm{P}_{\text {app }}$ of LY was greater in control cells (1.2$\left.1.4 \times 10^{-5} \mathrm{~cm} / \mathrm{s}\right)$ than in the monolayers treated with epigallocatechin $\left(7.0-6.4 \times 10^{-6} \mathrm{~cm} / \mathrm{s}\right)$, quercetin $\left(7.8-6.7 \times 10^{-6} \mathrm{~cm} / \mathrm{s}\right)$, or curcumin $\left(4.7-5.7 \times 10^{-6} \mathrm{~cm} / \mathrm{s}\right)$, indicating a reduction in intercellular space.

With regard to the use of these polyphenols as dietary supplements, it must be emphasized that they are all derived from foods, mostly from plants, and therefore they form part of the diet; moreover, they are considered to be substances with a GRAS (generally recognized as safe) status. Curcumin has also been authorized as a food additive by the European Union, with maximum permitted use levels varying from 20 to $500 \mathrm{mg} / \mathrm{kg}$ food. $^{41}$ The JECFA Committee allocated an acceptable daily intake of $0-3 \mathrm{mg} / \mathrm{kg}$ body weight. ${ }^{42}$ The curcumin concentrations used in the present study were within this range. No limitations have been placed on consumption of quercetin and epigallocatechin gallate. After a critical evaluation of the available literature on the biological effects of quercetin, including data related to safety, Harwood et al. ${ }^{43}$ concluded that, at estimated dietary intake levels, quercetin would not produce adverse health effects. Furthermore, the studies that have been conducted have also demonstrated the safety of epigallocatechin gallate as a supplement. $^{44,45}$

Another point worth noting derived from the present study is that not only pure compounds are effective in reducing absorption of inorganic As by intestinal cells; plant 
extracts rich in thiol groups or catechins and Fe supplements are also effective. Moreover, intake of these supplements can provide substantial antioxidant and anti-inflammatory activity, $^{46,47}$ acting on some of the toxic effects attributed to inorganic As. ${ }^{48,49}$ The reductions observed in the samples, including rice samples, as a result of using these extracts were very considerable (up to 70\%).

The data obtained in the present study show that there are dietary components or supplements that can reduce the oral bioavailability of As and that they could be used to reduce the toxicity of inorganic As, especially in populations chronically exposed to this metalloid. As the results show, they would be useful both if As is conveyed through drinking water or if it is consumed in foods with high concentrations of the inorganic forms. In vivo studies are needed to confirm what was observed in vitro, and to ensure that the use of strategies of this kind do not present risks.

\section{NOTES}

The authors declare no competing financial interest.

\section{FUNDING SOURCES}

This work was supported by the Spanish Ministry of Economy and Competitiveness (AGL2012-33461; AGL2015-68920-R), for which the authors are deeply indebted.

\section{REFERENCES}

1. Hughes, M.F.; Beck, B.D.; Chen, Y.; Lewis, A.S.; Thomas, D.J. Arsenic exposure and toxicology: a historical perspective. Toxicol. Sci. 2011, 123, 305-332. 
2. European Food Safety Agency (EFSA). Panel on Contaminants in the Food Chain (CONTAM); Scientific Opinion on Arsenic in Food. EFSA J. 2009, 7(10), 1-1351.

3. Almela, C.; Algora, S.; Benito, V.; Clemente, M.J.; Devesa, V.; Súñer, M.A.; Vélez, D.; Montoro, R. Heavy metal, total arsenic, and inorganic arsenic contents of algae food products. J. Agric. Food Chem. 2002, 50, 918-923.

4. Food Standards Agency (FSA). Consumers advised not to eat hijiki seaweed. 2010. (https://www.food.gov.uk/multimedia/hijikiqanda) (Accessed November 2016).

5. Canadian Food Inspection Agency (CFIA). Inorganic arsenic and hijiki seaweed consumption. 2012 (http://www.inspection.gc.ca/food/information-for-consumers/factsheets-and-infographics/specific-products-and-risks/chemical-hazards/inorganicarsenic/eng/1332268146718/1332268231124) (Accessed November 2016).

6. European Food Safety Agency (EFSA). Dietary exposure to inorganic arsenic in the European population. Scientific report of EFSA. EFSA J. 2014, 12 (3), 1-3597.

7. Joint FAO/WHO Expert Committee on Food Additives (JECFA). Evaluation of certain contaminants in food. Seventy-second report of the Joint FAO/WHO Expert Committee on Food Additives. WHO Technical Report Series, no. 959. WHO Library Cataloguingin-Publication Data, World Health Organization, 2011.

8. Díaz, O.P.; Leyton, I.; Muñoz, O.; Núñez, N.; Devesa, V.; Súñer, M.A.; Vélez, D.; Montoro, R. Contribution of water, bread, and vegetables (raw and cooked) to dietary intake of inorganic arsenic in a rural village of Northern Chile. J. Agric. Food Chem. 2004, 52, 1773-1779.

9. Ma, J.F.; Yamaji, N.; Mitani, N.; Xu, X.Y.; Su, Y.H.; McGrath, S.P.; Zhao, F.J. Transporters of arsenite in rice and their role in arsenic accumulation in rice grain. Proc. Natl. Acad. Sci. USA. 2008, 105, 9931-9935. 
10. Ma, J.F.; Tamai, K.; Ichii, M.; Wu, G.F. A rice mutant defective in Si uptake. Plant Physiol. Toxicol. Lett. 2002, 130, 2111-2117.

11. Meharg, A.A.; Zhao, F.-J. Strategies for producing low arsenic rice. In Arsenic \& Rice. Meharg, A.A., Zhao, F.-J. Eds.; Springer: Netherlands, 2012; pp. 139-155.

12. Juhasz, A.L.; Smith, E.; Weber, J.; Rees, M.; Rofe, A.; Kuchel, T.; Sansom, L.; Naidu, R. Application of an in vivo swine model for the determination of arsenic bioavailability in contaminated vegetables. Chemosphere 2008, 71, 1963-1969.

13. Vázquez, M.; Calatayud, M.; Jadán-Piedra, C.; Chiocchetti, G.M.; Vélez, D.; Devesa, V. Toxic trace elements at gastrointestinal level. Food Chem. Toxicol. 2015, 86, 163175.

14. Jadán-Piedra, C.; Clemente, M.J.; Devesa, V.; Vélez, D. Influence of physiological gastrointestinal parameters on the bioaccessibility of mercury and selenium from swordfish. J. Agric. Food Chem. 2016, 64, 690-698.

15. Muñoz, O.; Díaz, O.P.; Leyton, I.; Núñez, N.; Devesa, V.; Súñer, M.A.; Vélez, D.; Montoro, R. Vegetables collected in the cultivated Andean area of Northern Chile. Total and inorganic arsenic contents in raw vegetables. J. Agric. Food Chem. 2002, 50, 642-647.

16. Torres-Escribano, S.; Leal, M.; Vélez, D.; Montoro, R. Total and inorganic arsenic concentrations in rice sold in Spain, effect of cooking, and risk assessments. Environ. Sci. Technol. 2008, 42, 3867-3872.

17. Calatayud, M.; Gimeno, J.; Vélez, D.; Devesa, V.; Montoro, R. Characterization of the intestinal absorption of arsenate, monomethylarsonic acid, and dimethylarsinic acid using the Caco-2 cell line. Chem. Res. Toxicol. 2010, 23, 547-556. 
18. Calatayud, M.; Devesa, V.; Montoro, R.; Vélez, D. In vitro study of intestinal transport of arsenite, monomethylarsonous acid, and dimethylarsinous acid by Caco-2 cell line. Toxicol. Lett. 2011, 204, 127-133.

19. Calatayud, M.; Vázquez, M.; Devesa, V.; Vélez, D. In vitro study of intestinal transport of inorganic and methylated arsenic species by Caco-2/HT29-MTX cocultures. Chem. Res. Toxicol. 2012, 25, 2654-2662.

20. Tavelin, S.; Taipalensuu, J.; Soderberg, L.; Morrison, R.; Chong, S.; Artursson, P. Prediction of the oral absorption of low-permeability drugs using small intestine-like 2/4/A1 cell monolayers. Pharm. Res. 2003, 20, 397-405.

21. Roychowdhury, T.; Uchino, T.; Tokunaga, H.; Ando, M. Survey of arsenic in food composites from an arsenic-affected area of West Bengal, India. Food Chem. Toxicol. 2002, 40, 1611-1621.

22. Juhasz, A.L.; Smith, E.; Weber, J.; Rees, M.; Rofe, A.; Kuchel, T.; Sansom, L.; Naidu, R. In vivo assessment of arsenic bioavailability in rice and its significance for human health risk assessment. Environ. Health Perspect. 2006, 114, 1826-1831.

23. Roberts, S.M.; Weimar, W.R.; Vinson, J.R.; Munson, J.W.; Bergeron, R.J. Measurement of arsenic bioavailability in soil using a primate model. Toxicol. Sci. 2002, 67, 303-310.

24. Clemente, M.J.; Devesa, V.; Vélez, D. Dietary strategies reduce the bioaccessibility of arsenic from food matrices. J. Agric. Food Chem. 2016, 64, 923-931.

25. Han, B.; Runnells, T.; Zimbron, J.; Wickramasinghe, R. Arsenic removal from drinking water microfiltration by flocculation and microfiltration. Desalinization 2002, 145, 293298. 
26. Roberts, L.C.; Hug, S.J.; Ruettimann, T.; Billah, M.; Khan, A.W.: Rahman, M.T. Arsenic removal with iron(II) and iron(III) in waters with high silicate and phosphate concentrations. Environ. Sci. Technol. 2004, 38, 307-315.

27. Song, S.; Lopez-Valdivieso, A.; Hernandez-Campos, D.J.; Peng, C.; MonroyFernandez, M.G.; Razo-Soto, I. Arsenic removal from high-arsenic water by enhanced coagulation with ferric ions and coarse calcite. Water Res. 2006, 40, 364-372.

28. Liu, S.; Guo, X.; Zhang, X.; Cui, Y.; Zhang, Y.; Wu, B. Impact of iron precipitant on toxicity of arsenic in water: a combined in vivo and in vitro study. Environ. Sci. Technol. 2013, 47, 3432-3438.

29. Institute of Medicine. Food and Nutrition Board (IOM). Dietary Reference Intakes for Vitamin A, Vitamin K, Arsenic, Boron, Chromium, Copper, Iodine, Iron, Manganese, Molybdenum, Nickel, Silicon, Vanadium, and Zinc: a Report of the Panel on micronutrients. Washington, DC: National Academy Press, 2001.

30. Shen, S.; Li, X.F.; Cullen, W.R.; Weinfeld, M.; Le, X.C. Arsenic binding to proteins. Chem. Rev. 2013, 113, 7769-7792.

31. Alonzo, G.; Bertazzi, N.; Consiglio, M. Arsenic, antimony and bismuth complexation by L-cysteine in water. Inorg. Chim. Acta 1984, 85, L35-L37.

32. Scientific Committee for Food (SCF). First addendum to the Reports of the Scientific Committee on Food concerning the essential requirements of infant formulae and follow-up milks based on cow’s milk proteins and the minimum requirements for soyabased infant formulae and follow-up milks. Reports of the Scientific Committee for Food, (24th series). European Commission, Luxembourg, 1991. 
33. Commission Directive 96/5/EC, Euratom of 16 February 1996 on processed cerealbased foods and baby foods for infants and young children. OJ L 49, 28.2.1996, pp. 1728.

34. Commission Directive 2006/82/EC of 23 October 2006 adapting Directive 91/321/EEC on infant formulae and follow-on formulae and Directive 1999/21/EC on dietary foods for special medical purposes, by reason of the accession of Bulgaria and Romania. OJ L 362, 20.12.2006, pp. 94-96.

35. Commission Directive 2001/15/EC of 15 February 2001 on substances that may be added for specific nutritional purposes in foods for particular nutritional uses. OJ L 52, 22.2.2001, pp. 19-25.

36. European Food Safety Agency (EFSA). Opinion of the Scientific Panel on Food Additives, Flavourings, Processing Aids and Materials in Contact with Food. The use of L-cysteine in foods intended for infants and young children, Question n ${ }^{\circ}$ EFSA Q-2005083. EFSA J. 2006, 390, 1-7.

37. Amasheh, M.; Schlichter, S.; Amasheh, S.; Mankertz, J.; Zeitz, M.; Fromm, M.; Schulzke, J.D. Quercetin enhances epithelial barrier function and increases claudin-4 expression in Caco-2 cells. J. Nutr. 2008, 138, 1067-1073.

38. Redan, B.; Ferruzzi, M. Differentiated Caco-2 cell monolayers exhibit differential adaptation to chronic exposure of green tea and grape seed extracts rich in flavan-3-ols. FASEB J. 2015, 29, Supplement 249.4.

39. Wang, N.; Wang, G.; Hao, J.; Ma, J.; Wang, Y.; Jiang, X.; Jiang, H. Curcumin ameliorates hydrogen peroxide-induced epithelial barrier disruption by upregulating heme oxygenase-1 expression in human intestinal epithelial cells. Dig. Dis. Sci. 2012, 57, 1792-1801. 
40. Kim, C.Y.; Kim, K.H. Curcumin prevents leptin-induced tight junction dysfunction in intestinal Caco-2 BBe cells. J. Nutr. Biochem. 2014, 25, 26-35.

41. European Parliament and Council Directive 94/36/EC of 30 June 1994 on colours for use in foodstuffs. OJ L 273, 10.9.94, p.13.

42. Joint FAO/WHO Expert Committee on Food Additives (JECFA). Evaluation of certain food additives and contaminants. Sixty-first report of the Joint FAO/WHO Expert Committee on Food Additives. WHO Technical Report Series 922. Geneva, 2004.

43. Harwood, M.; Danielewska-Nikiel B.; Borzelleca J.F.; Flamm G.W.; Williams, G.M.; Lines, T.C. A critical review of the data related to the safety of quercetin and lack of evidence of in vivo toxicity, including lack of genotoxic/carcinogenic properties. Food Chem. Toxicol. 2007, 45, 2179-2205.

44. Chow, H.H.; Cai, Y.; Hakim, I.A.; Crowell, J.A.; Shahi, F.; Brooks, C.A.; Dorr, R.T.; Hara, Y.; Alberts, D.S. Pharmacokinetics and safety of green tea polyphenols after multiple-dose administration of epigallocatechin gallate and polyphenon $\mathrm{E}$ in healthy individuals. Clin. Cancer Res. 2003, 9, 3312-3319.

45. Isbrucker, R.A.; Bausch, J.; Edwards, J.A.; Wolz, E. Safety studies on epigallocatechin gallate (EGCG) preparations. Part 1: genotoxicity. Food Chem. Toxicol. 2006, 44, 626635.

46. Borek, C. Antioxidant health effects of aged garlic extract. J. Nutr. 2001, 131, 1010S1015S.

47. Thring, T.S.A.; Hili, P.; Naughton, D.P. Antioxidant and potential anti-inflammatory activity of extracts and formulations of white tea, rose, and witch hazel on primary human dermal fibroblast cells. J. Inflamm. 2011, 8, 27. 
48. Calatayud, M.; Devesa, V.; Vélez, D. Differential toxicity and gene expression in Caco2 cells exposed to arsenic species. Toxicol. Lett. 2013, 218, 70-80.

49. Calatayud, M.; Gimeno-Alcañiz, J.V.; Vélez, D.; Devesa, V. Trivalent arsenic species induce changes in expression and levels of proinflammatory cytokines in intestinal epithelial cells. Toxicol. Lett. 2014, 224, 40-46. 
Table 1. Dietary Strategies (Pure Dietary Compounds, Extracts, or Supplements) Used in the in vitro Bioavailability Assays of Arsenic Standard Solutions and Food Matrices.

\begin{tabular}{|c|c|c|c|}
\hline & $\begin{array}{c}\text { Concentration } \\
\text { (arsenic standard } \\
\text { solutions) }\end{array}$ & $\begin{array}{c}\text { Concentration } \\
\text { (food matrix) }\end{array}$ & Brand \\
\hline \multicolumn{4}{|l|}{ Pure dietary compounds } \\
\hline Sodium taurocholate & $2 \mathrm{mM}$ & n.a. & Sigma-Aldrich \\
\hline Iron(II) sulfate heptahydrate & $5 \mathrm{mg} / \mathrm{L}$ & $50 \mathrm{mg} / \mathrm{L}$ & Sigma-Aldrich \\
\hline Iron(III) sulfate hydrate & $5 \mathrm{mg} / \mathrm{L}$ & n.a. & Scharlau \\
\hline L-Cysteine (L-Cys) & $20 \mathrm{mg} / \mathrm{L}$ & $100 \mathrm{mg} / \mathrm{L}$ & Merck \\
\hline Homocysteine (Hcys) & $5 \mathrm{mg} / \mathrm{L}$ & n.a. & Sigma-Aldrich \\
\hline Choline chloride & $5 \mathrm{mg} / \mathrm{L}$ & n.a. & Sigma-Aldrich \\
\hline L-glutathione reduced (GSH) & $5 \mathrm{mM}$ & n.a. & Sigma-Aldrich \\
\hline Copper sulfate & $0.01 \mathrm{mM}$ & n.a. & Sigma-Aldrich \\
\hline Catechin hydrate & $10 \mathrm{mg} / \mathrm{L}$ & n.a. & Fluka \\
\hline Epicatechin & $10 \mathrm{mg} / \mathrm{L}$ & n.a. & Sigma-Aldrich \\
\hline Epigallocatechin & $10 \mathrm{mg} / \mathrm{L}$ & $100 \mathrm{mg} / \mathrm{L}$ & Sigma-Aldrich \\
\hline Calcium chloride & $50 \mathrm{mg} / \mathrm{L}$ & n.a. & Fluka \\
\hline Quercetin dihydrate & $10 \mathrm{mg} / \mathrm{L}$ & $40 \mathrm{mg} / \mathrm{L}$ & Sigma-Aldrich \\
\hline Ammonium phosphate & $25 \mathrm{mM}$ & $100 \mathrm{mM}$ & Merck \\
\hline Magnesium chloride & $20 \mathrm{mg} / \mathrm{L}$ & $100 \mathrm{mg} / \mathrm{L}$ & Sigma-Aldrich \\
\hline Seleno-D-L-methionine (SeMet) & $2 \mathrm{mg} / \mathrm{L}$ & n.a. & Sigma-Aldrich \\
\hline Methionine & $20 \mathrm{mg} / \mathrm{L}$ & n.a. & Panreac \\
\hline Se(IV) & $1 \mathrm{mg} / \mathrm{L}$ & n.a. & Merck \\
\hline Curcumin & $10 \mathrm{mg} / \mathrm{L}$ & $40 \mathrm{mg} / \mathrm{L}$ & Sigma-Aldrich \\
\hline Chitosan & $5 \mathrm{mg} / \mathrm{L}$ & n.a. & Sigma-Aldrich \\
\hline Thiamine & $50 \mathrm{mg} / \mathrm{L}$ & n.a. & Sigma-Aldrich \\
\hline $\mathrm{Zn}\left(\mathrm{NO}_{3}\right)_{2}$ & $5 \mathrm{mg} / \mathrm{L}$ & n.a. & Merck \\
\hline Dihydrolipoic acid (DHLA) & $25 \mathrm{mg} / \mathrm{L}$ & n.a. & Sigma-Aldrich \\
\hline Lecithin & $20 \mathrm{mg} / \mathrm{L}$ & n.a. & Sigma-Aldrich \\
\hline Albumin & $50 \mathrm{mg} / \mathrm{L}$ & n.a. & Sigma-Aldrich \\
\hline \multicolumn{4}{|l|}{ Extracts and supplements } \\
\hline Green tea extract & $25 \mathrm{mg} / \mathrm{L}$ & n.a. & Plantextrakt \\
\hline Grape seed extract & $25 \mathrm{mg} / \mathrm{L}$ & $100 \mathrm{mg} / \mathrm{L}$ & Plantextrakt \\
\hline Garlic extract & 25 mg/L & n.a. & Soria Natural \\
\hline Cocoa extract & $25 \mathrm{mg} / \mathrm{L}$ & n.a. & Naturex \\
\hline Broccoli extract & $25 \mathrm{mg} / \mathrm{L}$ & n.a. & Soria Natural \\
\hline Artichoke extract & $25 \mathrm{mg} / \mathrm{L}$ & $100 \mathrm{mg} / \mathrm{L}$ & Sakai \\
\hline Ferrous sulfate supplement & $25 \mathrm{mg} / \mathrm{L}$ & $50 \mathrm{mg} / \mathrm{L}$ & Tardyferon $80 \mathrm{mg}$ \\
\hline
\end{tabular}

n.a.: not assayed. 
Table 2. Apparent Permeability Coefficient $\left(\mathrm{P}_{\mathrm{app}}\right)$, and Cell and Mucus Retention (ng) in NCM-460 Monocultures and NCM-460/HT29-MTX Co-cultures (80/20) Exposed to 0.75 mg/L $(1 \mu \mathrm{M})$ of As(III) and As(V) for 2 Hours. Values Expressed as Mean \pm SD $(n=3)$.

\begin{tabular}{|c|c|c|c|c|}
\hline Cell culture type & As species & $\begin{array}{c}\mathbf{P}_{\text {app }} \\
\left(\times \mathbf{1 0}^{-5}, \mathbf{c m} / \mathbf{s}\right)\end{array}$ & $\begin{array}{c}\text { Cell retention } \\
\mathbf{( n g})\end{array}$ & $\begin{array}{c}\text { Mucus retention } \\
\text { (ng) }\end{array}$ \\
\hline \multirow{2}{*}{ NCM-460 } & As(III) & $3.4 \pm 0.2$ & $3.0 \pm 1.9$ & n.a. \\
\cline { 2 - 5 } & As(V) & $2.0 \pm 0.2$ & $<$ LOD & n.a. \\
\hline \multirow{2}{*}{ NCM 460/HT29-MTX } & As(III) & $3.8 \pm 0.1$ & $13 \pm 3.2$ & $13 \pm 2$ \\
\cline { 2 - 5 } & As(V) & $2.8 \pm 0.1$ & $14 \pm 1.7$ & $18 \pm 5$ \\
\hline
\end{tabular}

n.a.: not analyzed. 
Table 3. Arsenic Contents in the Bioaccessible Fraction Added to the Cell Cultures (Addition), Apparent Permeability Coefficient ( $\mathrm{P}_{\mathrm{app}}$ ) of Arsenic in NCM-460/HT29-MTX Co-Cultures (80/20) Exposed for 90 Minutes to the Bioaccessible Fraction of Rice Samples without or with the Dietary Strategies (Pure Dietary Compounds, Extracts, or Supplements), and Percentages of $\mathrm{P}_{\text {app }}$ Reduction of As in the Presence of these Strategies (Mean \pm Standard Deviation; $\mathrm{n}=3$ ). Asterisks $(*)$ Indicate Statistically Significant Differences in $\mathrm{P}_{\mathrm{app}}$ Values with Respect to the Assay Made without Dietary Strategies $(\mathrm{p}<$ $0.05)$.

\begin{tabular}{|c|c|c|c|}
\hline & $\begin{array}{c}\text { As addition } \\
\text { (ng) }\end{array}$ & $\begin{array}{c}P_{\mathrm{app}} \\
\left(\times 10^{-5} \mathrm{~cm} / \mathrm{s}\right)\end{array}$ & $\begin{array}{c}\mathbf{P}_{\text {app }} \text { reduction } \\
(\%)\end{array}$ \\
\hline \multicolumn{4}{|l|}{ Pure dietary compounds } \\
\hline Without compounds & 915 & 1.22 & \\
\hline Iron(II) sulfate (50 mg/L) & 908 & $0.969 *$ & $21 \pm 1.8$ \\
\hline Cysteine (100 mg/L) & 773 & $0.684 *$ & $44 \pm 7.2$ \\
\hline Epigallocatechin (100 mg/L) & 913 & $0.733 *$ & $40 \pm 5.5$ \\
\hline Quercetin (40 mg/L) & 707 & $0.793 *$ & $35 \pm 0.9$ \\
\hline Ammonium phosphate (100 mg/L) & 755 & $0.774 *$ & $37 \pm 4.9$ \\
\hline Magnesium chloride (100 mg/L) & 753 & $0.908 *$ & $26 \pm 2.6$ \\
\hline Curcumin (40 mg/L) & 740 & $0.368 *$ & $70 \pm 6.7$ \\
\hline \multicolumn{4}{|l|}{ Extracts and supplements } \\
\hline Without compounds & 759 & 0.332 & \\
\hline Iron(II) supplement (50 mg/L) & 720 & $0.155 *$ & $53 \pm 5.2$ \\
\hline Artichoke extract (100 mg/L) & 818 & $0.152 *$ & $54 \pm 7.5$ \\
\hline Grape extract (100 mg/L) & 716 & $0.125 *$ & $62 \pm 7.5$ \\
\hline
\end{tabular}


Table 4. Arsenic Contents in the Bioaccessible Fraction Added to the Cell Cultures (Addition), Apparent Permeability Coefficient ( $\mathrm{P}_{\mathrm{app}}$ ) of Arsenic in NCM-460/HT29-MTX Co-Cultures (80/20) Exposed for 90 Minutes to the Bioaccessible Fraction of Seaweed Samples without or with the Dietary Strategies (Pure Dietary Compounds, Extracts or Supplements), and the Percentages of $\mathrm{P}_{\mathrm{app}}$ Reduction of As in the Presence of these Strategies (Mean \pm Standard Deviation; $\mathrm{N}=3$ ). Asterisks (*) Indicate Statistically Significant Differences in $\mathrm{P}_{\text {app }}$ Values with Respect to the Assay Made without Dietary Strategies $(\mathrm{P}<0.05)$.

\begin{tabular}{|c|c|c|c|}
\hline & $\begin{array}{c}\text { As addition } \\
\text { (ng) }\end{array}$ & $\begin{array}{c}P_{\mathrm{app}} \\
\left(\times 10^{-5} \mathrm{~cm} / \mathrm{s}\right)\end{array}$ & $\begin{array}{c}\mathbf{P}_{\text {app }} \text { reduction } \\
(\%)\end{array}$ \\
\hline \multicolumn{4}{|l|}{ Pure dietary compounds } \\
\hline Without compounds & 404 & 1.58 & \\
\hline Iron(II) sulfate (50 mg/L) & 400 & $0.634 *$ & $59 \pm 1.9$ \\
\hline Cysteine (100 mg/L) & 410 & $0.976 *$ & $38 \pm 3.4$ \\
\hline Epigallocatechin (100 mg/L) & 405 & $0.738 *$ & $53 \pm 4.1$ \\
\hline Quercetin (40 mg/L) & 425 & $1.12 *$ & $29 \pm 2.7$ \\
\hline Ammonium phosphate (100 mg/L) & 381 & $0.749 *$ & $53 \pm 4.3$ \\
\hline Magnesium chloride (100 mg/L) & 404 & $1.04 *$ & $34 \pm 5.6$ \\
\hline Curcumin $(40$ mg/L) & 426 & $0.941 *$ & $40 \pm 2.0$ \\
\hline \multicolumn{4}{|l|}{ Extracts and supplements } \\
\hline Without compounds & 562 & 1.10 & \\
\hline Iron(II) supplement (50 mg/L) & 577 & 1.03 & $6 \pm 2.6$ \\
\hline Artichoke extract (100 mg/L) & 574 & $0.933 *$ & $15 \pm 6.4$ \\
\hline Grape extract (100 mg/L) & 571 & 1.03 & $6 \pm 1.5$ \\
\hline
\end{tabular}


Figure 1. Percentage of reduction in apparent permeability coefficients (Papp) in NCM-460 cells co-exposed to $0.75 \mathrm{mg} / \mathrm{L} \mathrm{As(III)}$ and the various dietary compounds $\left(37^{\circ} \mathrm{C}\right.$, 2 hours). The figure shows only the statistically significant reductions with respect to the assay made without dietary compounds $(\mathrm{p}<0.05)$.

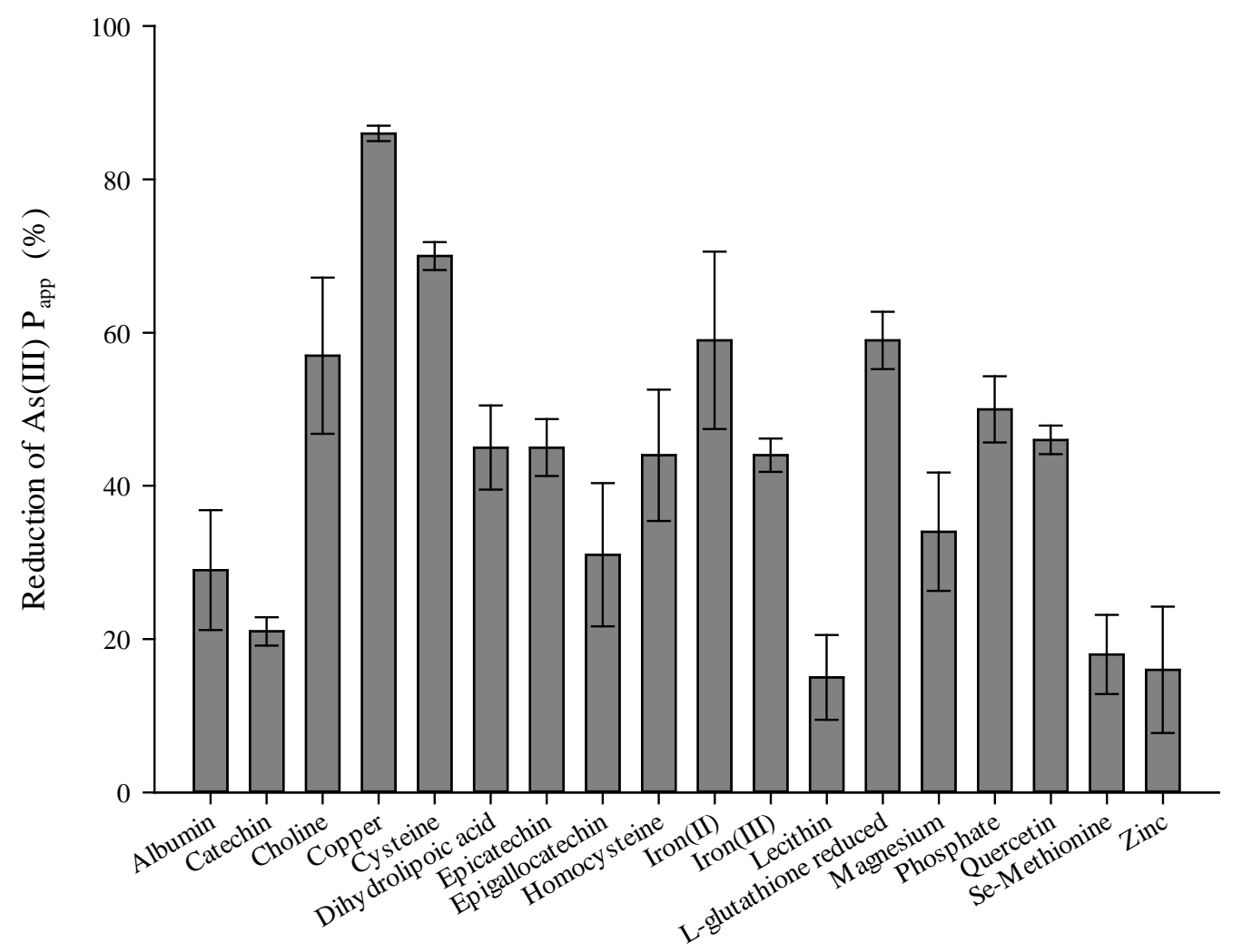


Figure 2. Percentage of reduction in the apparent permeability coefficients $\left(\mathrm{P}_{\text {app }}\right)$ in NCM460 cells co-exposed to $0.75 \mathrm{mg} / \mathrm{L} \mathrm{As}(\mathrm{V})$ and the various dietary compounds $\left(37^{\circ} \mathrm{C}, 2\right.$ hours). The figure shows only the statistically significant reductions with respect to the assay made without dietary compounds $(\mathrm{p}<0.05)$.

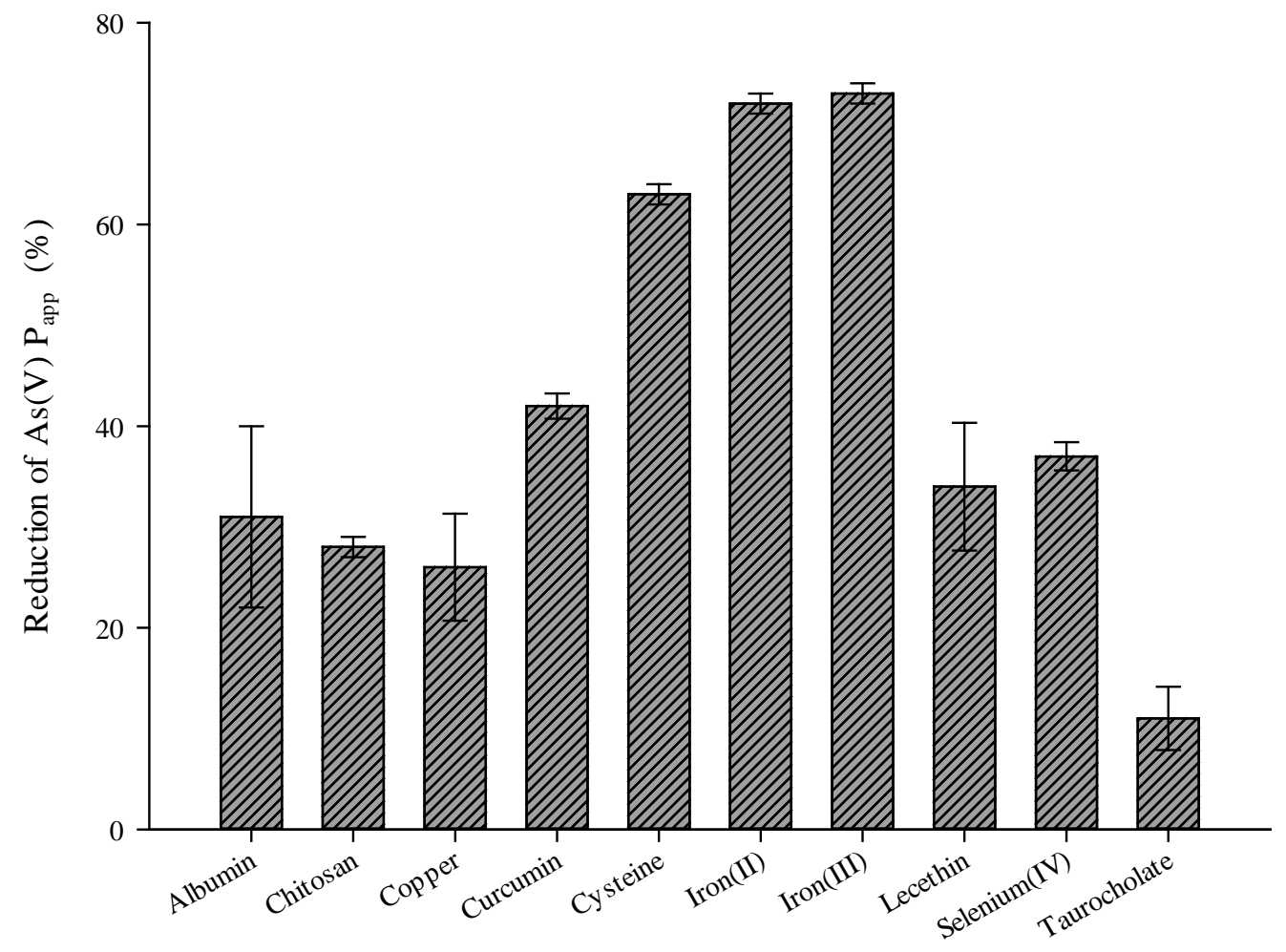


Figure 3. Percentage of reduction in the apparent permeability coefficients $\left(\mathrm{P}_{\text {app }}\right)$ in NCM460/HT29-MTX co-cultures (80/20) co-exposed to $0.75 \mathrm{mg} / \mathrm{L} \mathrm{As(III)} \mathrm{and} \mathrm{the} \mathrm{various}$ dietary compounds (37 ${ }^{\circ} \mathrm{C}, 2$ hours). The figure shows only the statistically significant reductions with respect to the assay made without dietary compounds $(\mathrm{p}<0.05)$.

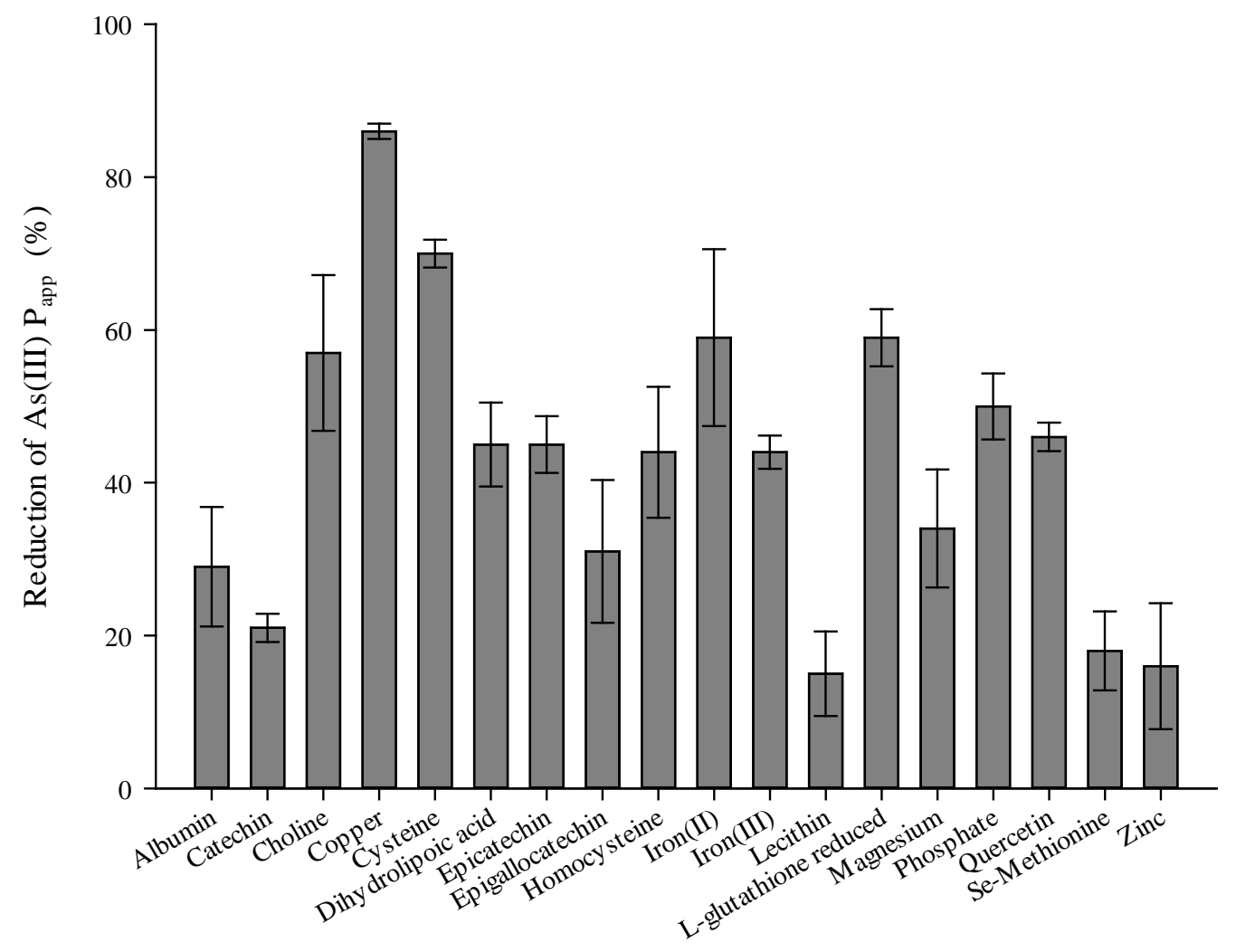


Figure 4. Percentage of reduction in the apparent permeability coefficients $\left(\mathrm{P}_{\text {app }}\right)$ in NCM460/HT29-MTX co-cultures (80/20) co-exposed to $0.75 \mathrm{mg} / \mathrm{L} \mathrm{As}(\mathrm{V})$ and the various dietary compounds (37 ${ }^{\circ} \mathrm{C}, 2$ hours). The figure shows only the statistically significant reductions with respect to the assay made without dietary compounds $(\mathrm{p}<0.05)$.

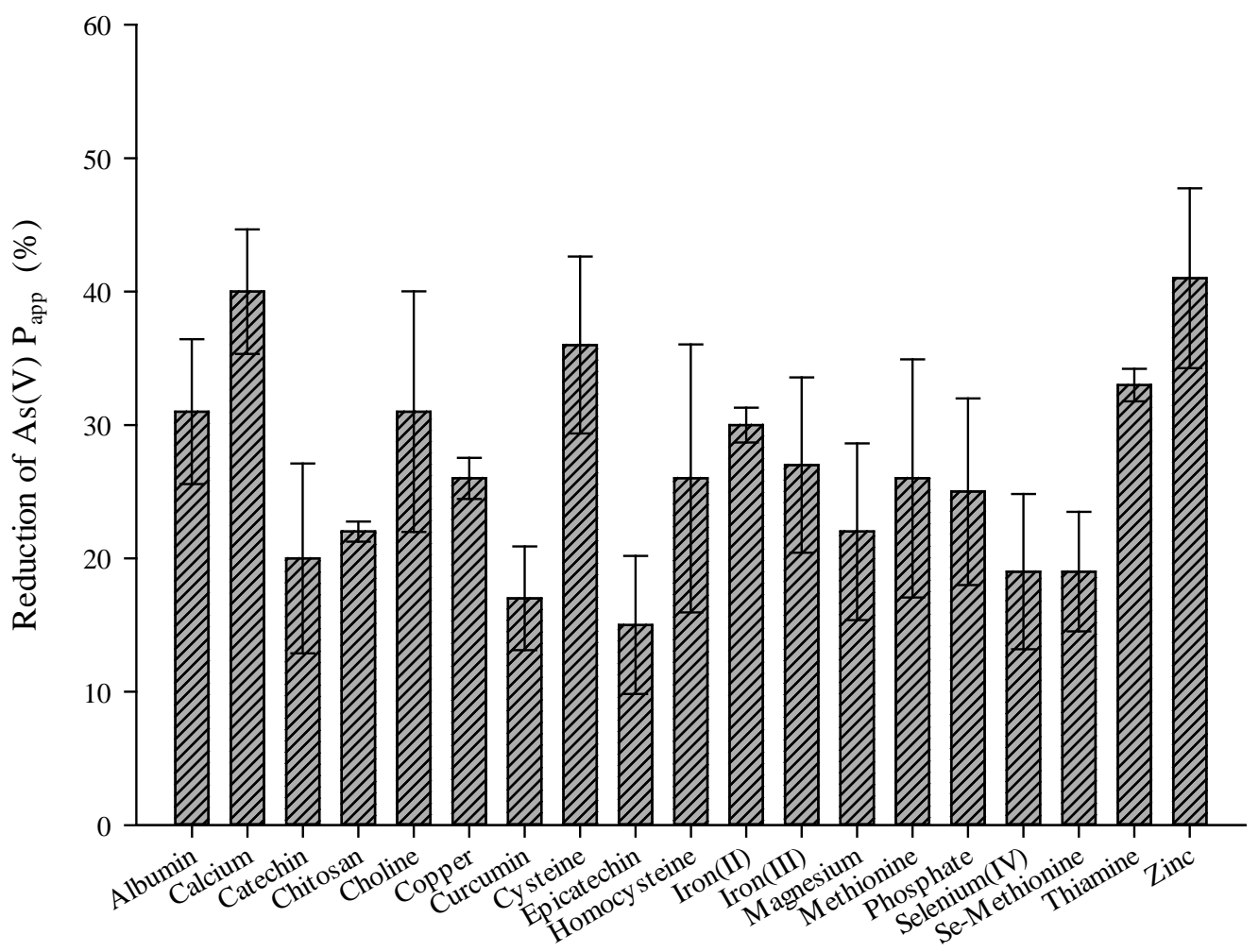


Figure 5. Percentage of reduction in the apparent permeability coefficients $\left(\mathrm{P}_{\text {app }}\right)$ in NCM460 monocultures co-exposed to $\mathrm{As}(\mathrm{III})$ or $\mathrm{As}(\mathrm{V})(0.75 \mathrm{mg} / \mathrm{L})$ and the various plant extracts or dietary supplements $\left(37^{\circ} \mathrm{C}, 2\right.$ hours). Asterisks indicate statistically significant reductions with respect to the assay made without extracts or supplements $(\mathrm{p}<0.05)$.

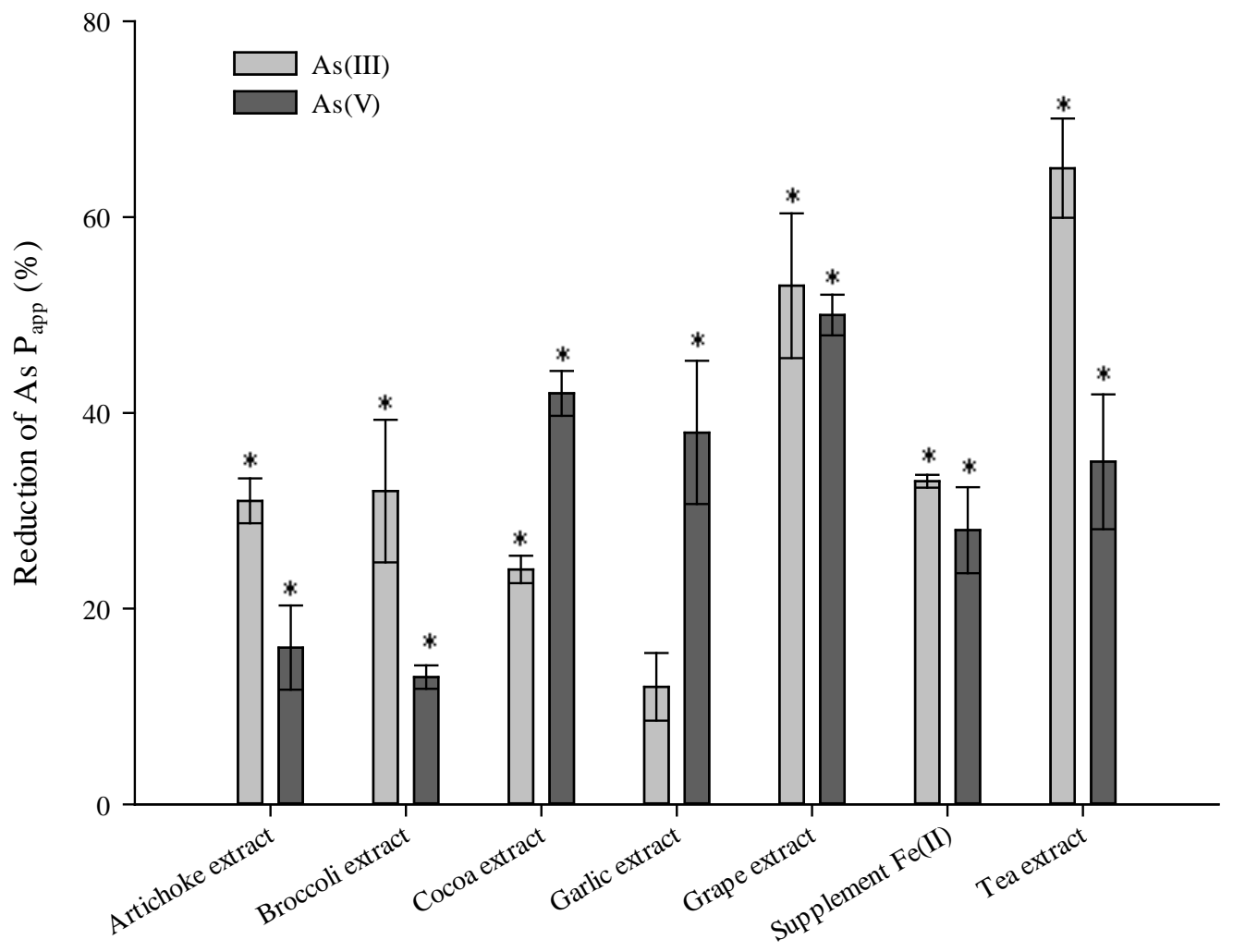


Figure 6. Percentage of reduction in the apparent permeability coefficients $\left(\mathrm{P}_{\text {app }}\right)$ in NCM460/HT29-MTX co-cultures co-exposed to As(III) or As(V) $(0.75 \mathrm{mg} / \mathrm{L})$ and the various plant extracts or dietary supplements $\left(37^{\circ} \mathrm{C}, 2\right.$ hours). Asterisks indicate statistically significant reductions with respect to the assay made without extracts or supplements ( $\mathrm{p}<$ $0.05)$.

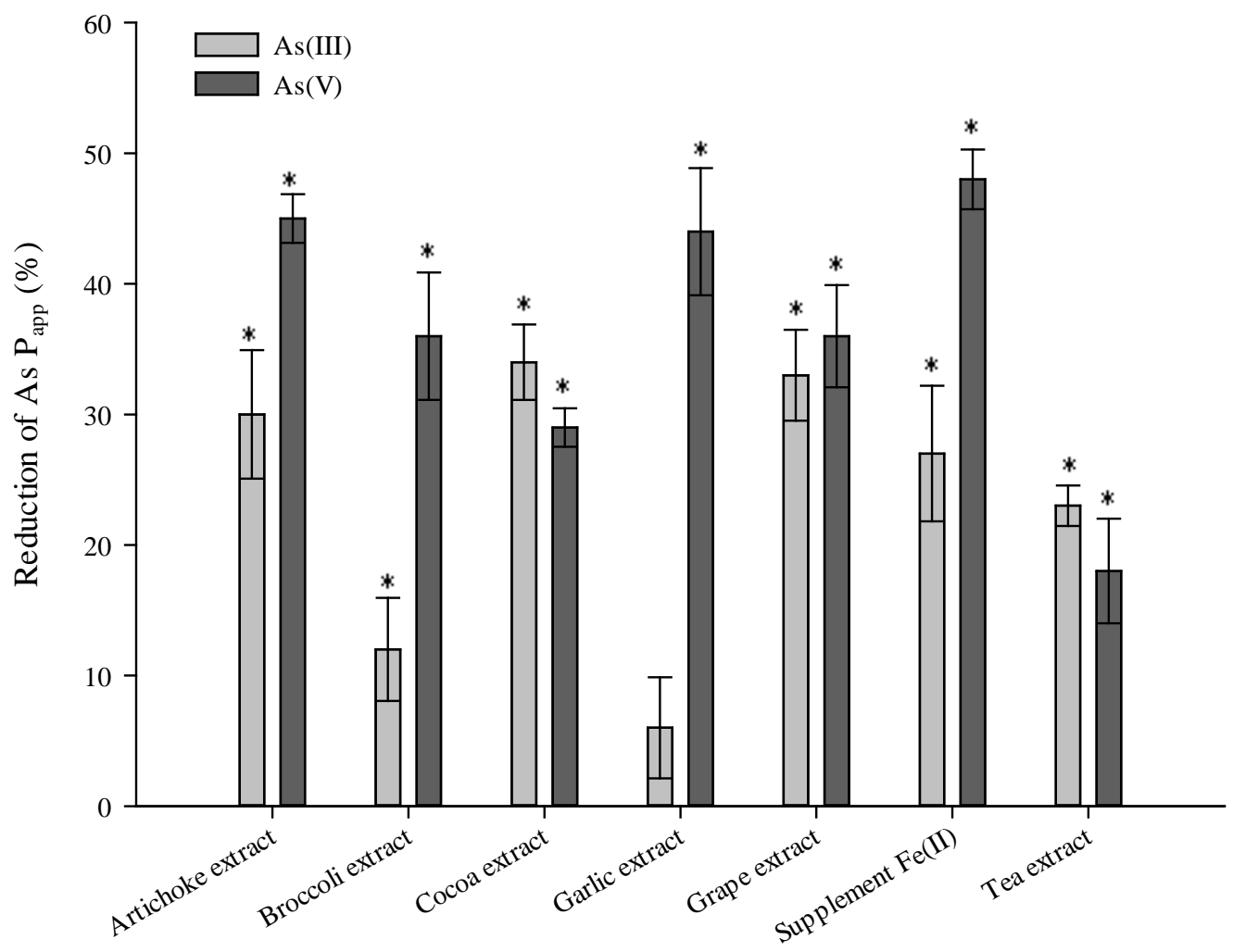




\section{Graphical abstract}

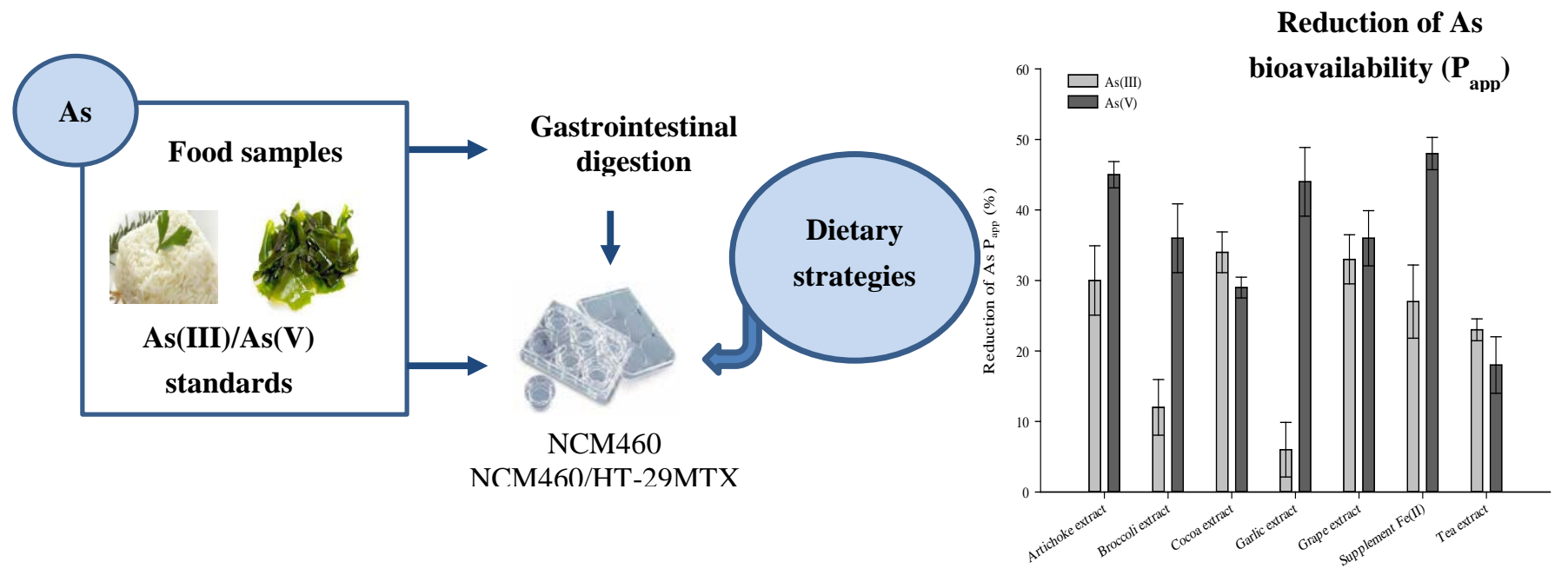

